\title{
Assessing intercultural competence (IC) of state junior high school English teachers in Yogyakarta
}

\author{
Mas Muhammad Idris \\ English Language Education, Graduate School, Yogyakarta State University, Jalan Colombo No. 1, Karangmalang, \\ Yogyakarta 55281, Indonesia
}

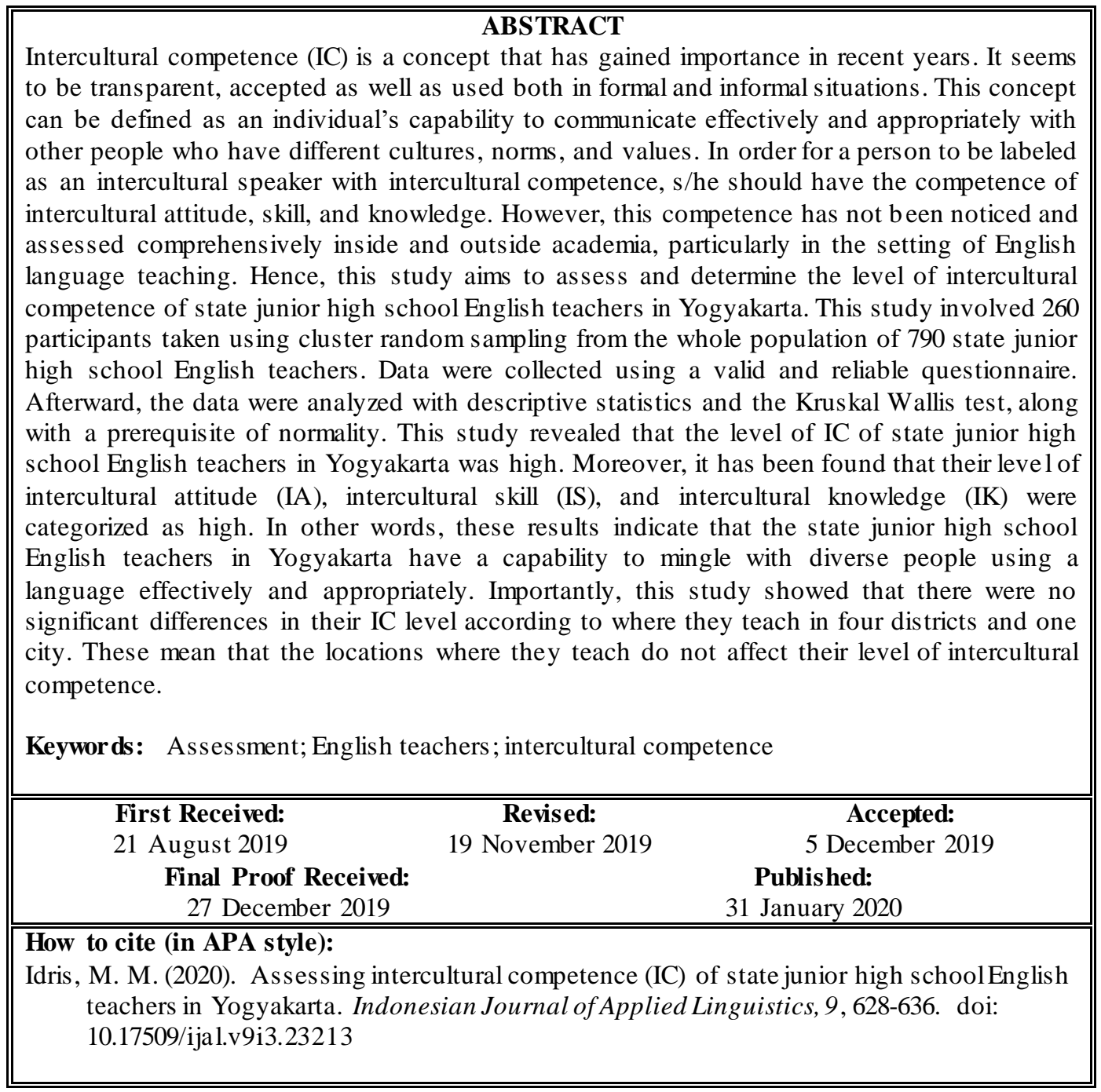

\section{INTRODUCTION}

Today, it is inevitable that people are connected easily with each other. This is due to some factors; for instance, the rapid globalization, the unstoppedtechnology, which is increased continuously from time to time, and the globalized societies which have developed their mutual aims pertinent to the long-term economic and cultural relationships. Therefore, developing intercultural competence (henceforth IC) as one of the key competencies in $21^{\text {st }}$-century life becomes pivotal (Delor, 1996; Idris, 2019, Sudhoff,
2010; UNESCO, 2006). The common nomenclature of virtually all definitions related to IC is that it is known as a sort of concept which has gained importance in recent years (Guncavdi \& Polat, 2016). Also, it is seen as a thing which seems to be transparent, received, understood as well as utilized in the context of both formal and informal conditions (Zheng, 2014). Regarding the concept of intercultural competence, it can be defined as the ability to communicate using the target language, for example English, effectively and appropriately and be able to mingle with different 
people who have diverse and multicultural backgrounds of cultures, norms, and values (Byram, Gribkova, \& Starkey, 2002; Idris, 2019; Setiadi, 2018).

One of the influential definitions related to educational context is from Huber and Reynolds (2014) who state that intercultural competence (IC) is the combination of attitude, skill, knowledge along with understanding and skills which are applied through intercultural activities. These activities will urge people to respect and understand other people's cultures properly as well as to communicate using the language effectively and appropriately so that they can build a good atmosphere when interacting with each other. Byram (1997) defines intercultural competence as individuals who possess the ability to interact with other people from different countries and cultures using their own language, their skill to interpret, analyze about cultural differences, also using their knowledge about intercultural communication as well as their attitudes of interest towards other cultures, values, and norms.

Furthermore, Byram et al. (2002) argue that intercultural competence is the ability to understand and communicate with other people who have different cultures and multiple identities using their intercultural knowledge, skill, and attitudes. Consequently, the intercultural speakers, they emphasize, should have the knowledge, skill, and good attitudes so that they could mingle with other people without any obstacles. According to Bennet (1993), intercultural competence is defined as a kind of developmental model that individuals acquire international global views through his model of intercultural sensitivity that has three stages of ethnocentrism (denial, defense, minimization), and three stages of ethnorelativism (acceptance, adaptation, integration). Furthermore, Bennet (1993) defines ethnocentris $m$ is that the center of one's culture is also apart from other cultures, while ethnorelativism is a culture that can be understood by other people via interaction and specific attitude in an intercultural context.

Another scholar, Fantini (2006) points out that the concept of intercultural competence is the complex abilities which are needed to be owned by people to interact with others using those abilities effectively and appropriately in intercultural situations. The abilities can be in the form of ability of knowledge, skill, and attitude. Moreover, Fantini (2009) states that the intercultural awareness becomes pivotal since it can influence other elements of intercultural competence. Thus, from all of these concepts, the intercultural competence is a kind of ability in which individuals need to have the intercultural knowledge, skill, attitude as well as intercultural awareness to perform in interaction effectively and appropriately using those abilities with other people who have different cultures and identities so that the mutual understanding are achieved. In the context of English language teaching, English teachers who learn and teach English should have not only the linguistics competence (e.g., how to communicate or write incorrect and appropriate ways) but also intercultural competence (IC) i.e. their ability to communicate with different people who have multicultural identities compared with their own through their language teaching and learning. As in the English language classroom, students who learn English subject need to understand about the English culture itself. For instance, in Indonesian context, when the students obtain the material related to the use of greeting of 'goodnight', they probably will have a misunderstanding in their conversation with others due to its meaning. Therefore, they need some intercultural knowledge as a part of intercultural competence, about what it means, how to use it in a proper situation so that they can minimize their mistakes. Hence, the role of English teachers who are supposed to understand about intercultural competence is also vital.

Added to this, Madya (2013) argues that Indonesian students have been naturally and nationally involved in the process of intercultural interaction due to the condition of multiculturalism that Indonesia has. The fact can be seen through a total of 350 ethnics and 746 languages. This means that Indonesian students have achieved the developmental process of intercultural competence. Although, there is still a possibility of miscommunication among them. It is due to the limited knowledge of their intercultural understanding. In other words, there is a need for Indonesian students to have knowledge of intercultural competence (IC). To attain this condition, it is demanded to design an integrated intercultural language learning which indicates that language and culture have a reciprocal relationship. Henceforth, the role of English teachers becomes vital since they have to assist their students in reaching that knowledge holistically. However, in doing so, the English teachers should first understand and possess those competencies, both linguistic competence, and intercultural competence. Additionally, according to Permendikbud No. 58 year 2013 chapter (5) point (6), it states that the English subject is taught since junior high school. It shows that students need to learn English early. Once the students learn the English language, they need to learn its culture too. Meaning that the students will learn not only the language but also the culture. They will learn other cultures as well as their own cultures. As a consequence, in this case, the junior high school English teachers should give knowledge about it before their students pursue their studies in higher education and could live in this discursive era.

According to Borghetti (2017), there are several reasons to assess intercultural competence in intercultural language education. First, if the IC is seen as one of the educational goals in language learning and teaching, it also appears logical enough to assess the learners' intercultural learning. Second, Sercu (2004), as cited in Borghetti (2017), argues that assessment is important due to its effect backwash towards the teaching and learning process. Last but not least, the assessment can affect the learners' motivation in their intercultural learning. Importantly, Scarino (2009) 
notices that the role of assessment is vital both in learning and using languages in diversity because (1) it sharpens the main focus on the nature of using and learning languages, (2) it gives the learners' information about their actual learning, and (3) it has a power to shape what language learning is; who the learners are; and what their understanding of language learning is important and it also can support the teaching and learning process since it is a natural part of it (Shuguang \& Qiufang, 2018). For these reasons, assessing intercultural competence cannot be ignored, respectively.

With respect to the importance of assessing intercultural competence (IC), numbers of studies have been taking shape the assessment of students' intercultural competence at university level (see Guncavdi \& Polat, 2016), the teachers' perceptions related to the implementation of IC assessment (see Xiaole, Meng \& Manli, 2012), the importance of integrating intercultural competence into the classroom practices (see Fungchomehoei \& Kardkarmkali, 2016), the assessment of ICC through EFL students' writing (see $\mathrm{Wu}, 2015$ ), the identification and assessment of intercultural competence as a student outcome of internationalization (see Deardorff, 2006), the assessment of intercultural sensitivity of pre-service English language teachers (see Altan, 2018; and Cubukcu, 2013), and the assessment of IC of vocational teachers (see Rajic \& Rajic, 2015); and teachers' intercultural competence and teacher education (see Pajak-Wazna, 2013). Thus, there has always been a need to assess intercultural competence in language teaching and learning even in doing so is a difficult task (Borghetti, 2017). However, this need is still considered a minimum in the literature of the urgency of assessing intercultural competence in the Indonesian context, especially for the assessment of teachers' level of IC that in contrast as Deardorff (2006) states that there should be always a possibility to assess the degree or level of intercultural competence. Therefore, the present study measures the intercultural competence (IC) of state junior high school English teachers in Yogyakarta Special Region province (hereafter DIY).

\section{METHOD}

\section{Respondents}

Respondents were 260 state junior high school English teachers from four districts, namely Sleman, Bantul, Gunung Kidul, Kulon Progo, and the city of Yogyakarta in DIY. The respondents were taken using cluster random sampling from the total population of 790 English teachers. They comprised 132 males (50.7\%) and 128 females $(49.2 \%)$. The $27.7 \%$ of the sample (72 English teachers) was from Sleman, the $9.61 \%$ of the sample (25 English teachers) was from Gunung Kidul, the $33.8 \%$ of the sample (88 English teachers) was from Bantul, the $10.7 \%$ of the sample (28 English teachers) was from Kulon Progo, and the $18.1 \%$ of the sample (47 English teachers) was from Yogyakarta City. Also, the respondents were from the first- to the third grade
English teaches and have been teaching English for almost 10 to 20 years.

\section{Instruments}

This study used an adapted questionnaire from the Pestalozzi Programme and the Intercultural Cities project of the Council of Europe/European Commission and the European Wergeland Centre (Lazar, 2008). This instrument was called Recognizing Intercultural Competence: What Shows That I am Interculturally Competent?. The real scale of this instruments consisted of 56 items that represented the main elements which made up the intercultural competence (IC) intercultural attitude (20 items) such as respect, tolerance of ambiguity, open-mindedness and curiosity, empathy, self-awareness, and confidence to challenge and be challenged, intercultural skill (22 items) such as interaction, multiperspectivity, critical thinking, problem solving and collaboration, and ability to grow, and intercultural knowledge (15 items) such as knowledge about interaction, social practice, the role of social and political actors, and world views and belief systems. All items were described in the form of Istatements and were formed as 5-Likert type. These items were then tailored to their design to the Indonesian context. The changes were 5 items included within the attitude indicators, 5 items included within the skill indicators, and 1 item included within the knowledge indicators. The purpose of changes was to gain deeper understanding pertinent to the elements of IC that could provide useful additional information. The respondents assessed their own attitudes, knowledge, and skills on a 5-point scale (1 - never, 2 - seldom, 3 sometimes, 4 - often, 5 - always). Also, the instrument was in the form of the Indonesian language. It was done to avoid misunderstanding of answering each item of the questionnaire. In addition, the researcher used criteria established by Ameida et al. (2012) in choosing this self-as sessment tool, as can be seen in Table 1 .

\section{Data Analysis and Procedures}

Descriptive and Kruskal Wallis tests were used to analyze the data with different procedures. The descriptive statistics was the first procedure to gain the data related to the level of intercultural competence (IC) along with its main elements, the intercultural attitude, intercultural skill, and intercultural knowledge. The researcher used the interval conversion of the intercultural competence level to categorize the level of IC (see Table 2).

The second was the Kruskal Wallis test. In this test, there were two phases, namely the prerequisite test and the Kruskal Wallis test. For the former, it was used to test the normality of the data. The result showed that the data were normally distributed since all the sig. values that could be seen through the Shapiro-Wilk test of normality, of Yogyakarta city (.373), Sleman (.835), Kulon Progo (.396), Gunung Kidul (.892), were bigger than 0.05 except Bantul (.000) which was smaller than 0.05 . The details were in Table 3 as the following. 
Table 1. Criteria in the selection of the instrument

\begin{tabular}{|c|c|}
\hline Criteria & $\begin{array}{l}\text { Description of Recognizing intercultural competence: What shows that I am interculturally } \\
\text { competent? applicability to this research }\end{array}$ \\
\hline 1. Construct validity & $\begin{array}{l}\text { It was developed by a group of } 30 \text { teachers, school heads, and experts from all over Europe in a } \\
\text { three-day Think Tank. It also tested by } 50 \text { teachers and school heads in } 14 \text { countries. The work was } \\
\text { under the Council of Europe and other international organizations. It was also co-organized by the } \\
\text { Pestalozzi Programme and the Intercultural Cities project of the Council of Europe and the European } \\
\text { Wegerland Centre. Additionally, the main elements that make up intercultural competence are } \\
\text { attitude which consists of sub-elements namely respect, tolerance of ambiguity, open-mindedness } \\
\text { and curiosity, empathy, self-awareness, and confidence to challenge and be challenged,skills that } \\
\text { comprises interaction, multiperspectivity, critical thinking, problem solving and collaboration, and } \\
\text { ability to grow as the sub-elements, and knowledge that divided into sub-elements namely } \\
\text { knowledge about interaction, social practice, the role of social and political actors, and world views } \\
\text { and belief systems. }\end{array}$ \\
\hline
\end{tabular}

2. Type of assessment This self-assessment tool fulfills the need for the author's research to disclose the target population's level of their IC level pertinent to the three elements of IC (attitude, skills, and knowledge).

3. Theory-grounded The several main theories related to this instrument were the theory referring to five experts (Barret, instrument Byram, Lazar, Mompoint-Gaillard, and Philippou) as well as from the shared expertise of the participants and the recent results of research and project work within the Council of Europe (2008) and other international organizations.

4. Response scale The scale formats of the response are within a range of 5 scales $(1-$ never, 2 - seldom, 3 format sometimes, 4 - often, 5 - always), respectively.

5. Reliability and validity of the measurement

Regarding the reliability and validity of this instrument, it is based on the piloting results of a questionnaire carried out to random-sampling respondents with the same characteristic that is the state junior high school English teachers.

6. Feasibility

The instrument is cost-free, it can be accessed online through https://www.coe.int/t/dg4/education/estalozzi/Source/Documentation/IC Tool2014/ICToolGB.pdf

7. Target population \& development

The targeted respondents in this research are the state junior high school English teachers' IC level of attitude, skill, and knowledge. levels

Table 2. Interval conversion of intercultural competence level

\begin{tabular}{ll}
\hline \multicolumn{1}{c}{ Score Interval } & Categories \\
\hline$x>\bar{X} i+1,8 S b_{i}$ & Very High \\
$\bar{X} i+0,6 S b_{i}<x \leq \bar{X} i+1,8 S b_{i}$ & High \\
$\bar{X} i-0,6 S b_{i}<x \leq \bar{X} i+0,6 S b_{i}$ & Medium \\
$\bar{X} i-1,8 S b_{i}<x \leq \bar{X} i-0,6 S b_{i}$ & Low \\
$x \leq \bar{X} i-1,8 S b_{i}$ & Very Low \\
\hline
\end{tabular}

Table 3. The result of Normality Test

\begin{tabular}{llcccccc}
\hline & \multicolumn{3}{c}{ Tests of Normality } \\
\hline & \multicolumn{2}{c}{ Place of Teaching } & \multicolumn{2}{c}{ Kolmogorov-Smirnov ${ }^{\mathrm{a}}$} & \multicolumn{3}{c}{ Shapiro-Wilk } \\
\cline { 3 - 7 } & & Statistic & Df & Sig. & Statistic & df & Sig. \\
\hline \multirow{2}{*}{ Level of IC Understanding } & Yogyakarta & .103 & 47 & $.200^{*}$ & .974 & 47 & .373 \\
& Sleman & .049 & 72 & $.200^{*}$ & .990 & 72 & .835 \\
& Kulon Progo & .116 & 28 & $.200^{*}$ & .962 & 28 & .396 \\
& Gunung Kidul & .085 & 25 & $.200^{*}$ & .980 & 25 & .892 \\
& Bantul & .082 & 88 & $.200^{*}$ & .935 & 88 & .000 \\
\hline
\end{tabular}

\section{*. This is a lower bound of the true significance.}

\section{a. Lilliefors Significance Correction}

The Kruskal Wallis test was used to test whether there were significant differences of the IC level of state junior high school English teachers according to where they taught in four districts, Sleman, Bantul, Kulon Progo, Gunung Kidul, and the city of Yogyakarta. If the sig. the value was bigger than 0.05 , and it meant that there were no significant differences among the variables.

\section{Research Problem and Hypothesis}

Regarding the research problem and the hypothesis, the author is eager to see the level of intercultural competence (IC) along with intercultural attitude (IA), intercultural skill (IS), and intercultural knowledge (IK) of state junior high school English teachers in Yogyakarta Special Region province and also to figure out whether any significant differences of levels of 
intercultural competence (IC) of state junior high school English teachers according to where they teach in the four districts (Sleman, Bantul, Gunung Kidul, and Kulon Progo) and the city of Yogyakarta in Yogyakarta Special Region province. In addition, the following hypotheses were made in order to see whether any significant differences or not of level of intercultural competence related to its three elements; attitude, skill, and knowledge based on where they teach in the four districts (Sleman, Bantul, Gunung Kidul, and Kulon Progo) and the city of Yogyakarta of state junior high schools in Yogyakarta.

\section{FINDINGS AND DISCUSSION}

The IC level of state junior high school in Special Region of Yogyakarta

Concerning the research problem, the result of descriptive statistics showed that the mean score of the intercultural competence (IC) level of the state junior high school English teachers in Yogyakarta Special Region province (DIY) was 156.38 (SD=16.234). Then, this mean score was referred to the below Table 4 by looking at the mean score which demonstrated that the state junior high school English teachers in Yogyakarta Special Region province (DIY) had a high intercultural competence (IC) level related to its three elements of IC namely attitude, skill, and knowledge.

\begin{aligned} & Table 4. Mean score of IC category \\ & \hline Mean Score \multicolumn{1}{c}{ Category } \\ & \hline $\mathbf{x}>\mathbf{1 6 8}$ Very High \\ & $\mathbf{1 3 6}<\mathbf{x} \leq \mathbf{1 6 8}$ High \\ & $\mathbf{1 0 4}<\mathbf{x} \leq \mathbf{1 3 6}$ Medium \\ & $\mathbf{7 2}<\mathbf{x} \leq \mathbf{1 0 4}$ Low \\ & $\mathbf{x} \leq \mathbf{4 0}$ Very Low \\ & \hline\end{aligned}

Moreover, the following chart expounds the detailed description of the intercultural competence (IC) level of the state junior high school English teachers in Yogyakarta Special Region province (DIY). There were found 53 English teachers who had a "very high" level of IC, 183 English teachers had a "high" level of IC, 23 English teachers had a "medium" level of IC, 1 English teacher had a "very low" level of IC, and none had a "low" level of IC.

The next result of descriptive statistics showed that the mean score of the intercultural attitude (IA) level of the state junior high school English teachers in Yogyakarta Special Region province (DIY) was 30.55 $(\mathrm{SD}=2.963)$. Then, this mean score was referred to in Table 5 by looking at the mean score, which demonstrated that the state junior high school English teachers in Yogyakarta Special Region province (DIY) had a high intercultural attitude (IA) level.

In addition, the following chart presents a detailed description of the intercultural attitude (IA) level of the state junior high school English teachers in Yogyakarta Special Region province (DIY). There were found 39 English teachers who had a "very high" level of IA, 183 English teachers had a "high" level of IA, 37 English teachers had a "medium" level of IA, 1 English teacher had a "low" level of IA, and none had a "very low" level of IA.

Table 5. Mean score of IA Category

\begin{aligned} & \hline Mean Score \multicolumn{1}{c}{ Category } \\ & $\mathbf{x}>\mathbf{3 3 . 6}$ Very High \\ & $\mathbf{2 7 . 2}<\mathrm{x} \leq \mathbf{3 3 . 6}$ High \\ & $\mathbf{2 0 . 8}<\mathrm{x} \leq \mathbf{2 7 . 2}$ Medium \\ & $\mathbf{1 4 . 4}<\mathrm{x} \leq \mathbf{2 0 . 8}$ Low \\ & $\mathbf{x} \leq \mathbf{8}$ Very Low \\ & \hline\end{aligned}

The other result of descriptive statistics showed that the mean score of intercultural skill (IS) level of the state junior high school English teachers in Yogyakarta Special Region province (DIY) was 87.98 (SD=10.089). Then, this mean score was referred to in Table 6 by looking at the mean score, which demonstrated that the state junior high school English teachers in Yogyakarta Special Region province (DIY) had a high intercultural skill (IS) level.

Table 6. Mean score of IS Category

\begin{tabular}{rc}
\hline Mean Score & Category \\
$\mathbf{x}>\mathbf{9 2 . 4}$ & Very High \\
$\mathbf{7 4 . 8}<\mathrm{x} \leq \mathbf{9 2 . 4}$ & High \\
$\mathbf{5 7 . 2}<\mathrm{x} \leq \mathbf{7 4 . 8}$ & Medium \\
$\mathbf{3 9 . 6}<\mathrm{x} \leq \mathbf{5 7 . 2}$ & Low \\
$\mathbf{x} \leq \mathbf{2 2}$ & Very Low \\
\hline
\end{tabular}

Furthermore, the following chart describes the detailed description of the intercultural skill (IS) level of the state junior high school English teachers in Yogyakarta Special Region province (DIY). There were found 79 English teachers who had a "very high" level of IS, 161 English teachers had a "high" level of IS, 17 English teachers had a "medium" level of IS, 3 English teacher had a "low" level of IS, and none had a "very low" level of IS.

The last result of descriptive statistics showed that the mean score of intercultural knowledge (IK) level of the state junior high school English teachers in Yogyakarta Special Region province (DIY) was 37.84 $(\mathrm{SD}=5.977)$. Then, this mean score was referred to in Table 7 by looking at the mean score, which demonstrated that the state junior high school English teachers in Yogyakarta Special Region province (DIY) had a high intercultural knowledge (IK) level. For detail of this descriptive statistics result of IS level.

Table 7. Mean Score of IK Category

\begin{aligned} \hline \multicolumn{1}{r}{ Mean Score } & \multicolumn{1}{c}{ Category } \\ \hline $\mathbf{x}>\mathbf{4 2} &$ Very High \\ \hline $\mathbf{3 4}<\mathbf{x} \leq \mathbf{4 2} &$ High \\ \hline $\mathbf{2 6}<\mathbf{x} \leq \mathbf{3 4} &$ Medium \\ \hline $\mathbf{1 8}<\mathbf{x} \leq \mathbf{2 6} &$ Low \\ \hline $\mathbf{x} \leq \mathbf{1 8} &$ Very Low \end{aligned}

In addition, the following chart expounds the detailed description of the intercultural knowledge (IK) 
level of the state junior high school English teachers in Yogyakarta Special Region province (DIY). There were found 52 English teachers who had a "very high" level of IK, 143 English teachers had a "high" level of IK, 58 English teachers had a "medium" level of IA, 8 English teacher had a "low" level of IK, and 1 English teacher had a "very low" level of IK.

\section{The description of the hypothesis result}

The result of Kruskal Wallis showed that the sig. values .551 is greater than 0.05 . It can be seen in Table 8. It meant that there were no significant differences among the state junior high school English teachers in Yogyakarta Special Region province of the level of intercultural competence (IC) following its three elements, attitude, skill, and knowledge.

This also meant that the result did not confirm the alternative hypothesis (H1) that there were significant differences of the level of IC of state junior high school English teachers in Yogyakarta Special Region province according to the locations (four regencies, namely Sleman, Bantul, Gunung Kidul, and Kulon Progo and one city, Yogyakarta) where they teach. In contrast, the result confirmed the null hypothesis (H0) that there were no significant differences of the level of IC of state junior high school English teachers in Yogyakarta Special Region province based on the locations (four regencies, Sleman, Bantul, Gunung Kidul, and Kulon Progo and one city, Yogyakarta).

Table 8. The Results of the Kruskal Wallis Test

\begin{tabular}{lr}
\hline & Level of IC \\
\hline Chi-Square & 3.040 \\
df & 4 \\
Asymp. Sig. & .551 \\
a. Kruskal Wallis Test & \\
b. Grouping Variable: Place of Teaching & \\
\hline
\end{tabular}

\section{DISCUSSION}

The main point of this research is to assess the state junior high school English teachers in Yogyakarta Special Region province (DIY) who will have a very low, low, medium, high, or very high intercultural competence (IC) related to its three elements, attitude, skill, and knowledge. In this section, the researcher discusses several points on the previous findings and relate them with the theories as well as some relevant previous studies.

The first result of descriptive statistics demonstrates that the state junior high school English teachers in Yogyakarta Special Region province have a high level of IC, as seen in Table 4. These results indicate that the state junior high school English teachers in DIY have high respect for cultural differences (Altan, 2018), and believes that they are able to behave pertinent to the proposed indicators (attitude, skill, and knowledge) properly (Rajic \& Rajic, 2015). Additionally, these results reflect that they also seem to perceive well on what they have understood about cultural differences, values, and norms so that they are able to easily input several cultural elements (see, Byram et al., 2002; Hong, 2008; Huber \& Reynolds, 2014; Kramsch, 2013) into their teaching and learning process. Furthermore, this high level of IC of the state junior high school English teachers in Yogyakarta Special Region province shows tolerance of ambiguity that they are willing to put their values and norms aside temporally. It is in accordance with the view of Huber \& Reynolds (2014) related to the essence of intercultural competence itself that IC involves respecting people who have a different cultural relationship from oneself. They further explain that the term "respect" means respecting all human beings even though they have different cultures, values, and norms.

The second result of descriptive statistics reveals that the state junior high school English teachers in DIY have a high intercultural attitude (IA) (see Table 5). Based on the notion of Byram (1997), this indicates that the state junior high school English teachers in DIY are considered to be able to succeed in intercultural interaction since they are open-minded with other people's cultures, beliefs, and behaviors. Moreover, the state junior high school English teachers are also supposed to have the attitudes of curiosity and openness, and of readiness to suspend judgment based on first impressions when they meet other people in an intercultural encounter. In addition, the state junior high school English teachers in DIY have also shown that they interact positively without the certainty of what the other thinks and feels. This means that they have applied their intercultural attitude through their action of a conversation with other people (Huber \& Reynolds, 2014).

Furthermore, this high intercultural attitude of the state junior high school English teachers shows awareness of the fact that their way of thinking and acting is influenced by a set of values and norms. Likewise, it also shows that they accept being challenged. This latter case indicates that the state junior high school English teachers are willing to seek out chances to have cooperation and mingle with other individuals who have different cultures, orientations, and perspectives from theirs (Huber \& Reynolds, 2014). One should have requisite attitudes, according to Deardorff (2006), in the forms of respect (valuing other cultures, cultural diversity), openness (to intercultural learning and people from other cultures, withholding judgment), and curiosity and discovery (tolerating ambiguity and uncertainty). Therefore, in this sense, it can be said that the state junior high school English teachers, through their high intercultural attitudes, have expressed that they have the requisite attitudes proposed, respectively.

The other result of this research is that the state junior high school English teachers possess a high intercultural skill (IS) (see Table 6). This result indicates that they have the ability to interact with other people who have different knowledge and skill of problem-solving as well as doing a collaboration with 
others. It also expounds that the state junior high school English teachers have shown their critical thinking. For example, they use all available information and their analytical skills to verify their interpretations. All of these are based on the result of descriptive statistics of the state junior high school English teachers' responses towards their individual state in answering the questionnaire related to one element of IC.

Moreover, the third result of descriptive statistics shows that the state junior high school English teachers possess a high intercultural knowledge (IK), as seen in Table 7. In light of the view of Huber and Reynolds (2014), this high intercultural knowledge expounds that the state junior high schoolEnglish teachers have shown their understanding towards a different kind of interaction that it has different aims and rules. In other words, they realize that every communication with other people who have different goals and rules needs knowledge about social practices so that misunderstanding can be minimized. In addition to this, the state junior high school English teachers also seem to be active in exploring the reasons behind different practices and reactions when they conduct a conversation with other people who show different behaviors or attitudes. Moreover, the most important part, since they have high intercultural knowledge, they possibly show awareness of the fact that other people might think, behave, and feel differently.

Above all, the highlight of the results is that the degree of intercultural competence of the state junior high school English teachers in Yogyakarta Special Region province has showed that they have an ability to communicate using the target language properly with other people who have different cultures, values, and norms in the form of doing an interaction in intercultural encounter, and they are also ready to mingle with the diverse human beings that have different orientations, goals, and rules. In addition, the results of descriptive statistics of this research are consistent with the finding study of Altan (2018), that having a high intercultural competence will enable one to respect other cultural differences. In this sense, the state junior high school English teachers have showed that they have the capability of doing so.

Beyond the above descriptive statistics' results, the finding which is based on the hypothesis reveals that there are no significant differences regarding the level of intercultural competence pertinent to its three elements (attitude, skill, and knowledge) amongst the state junior high school English teachers in Yogyakarta Special Region province. This means that all the state junior high school English teachers in Yogyakarta Special Region province seem to have the same adequate knowledge of how to involve the cultural elements into their teaching-learning process so that they are able to assist their students in gaining intercultural competence and making them become intercultural speakers. Once the students are considered as intercultural speakers, they possibly can cope and mingle with their fellas who have different cultures, norms, languages properly in term of doing communication in an intercultural situation.

Also, due to their same level related to IC's elements, this confirms the null hypothesis and disclose that there are no significant differences of level of intercultural competence (IC) according to the locations where the state junior high school English teachers in Yogyakarta Special Region province teach in the four regencies (Sleman, Bantul, Gunung Kidul, Kulon Progo) and the city of Yogyakarta. This result is consistent with the finding study of Rajic and Rajic (2015) and Guncavdi and Polat (2016), which reveal that the location does not influence the level of intercultural competence (IC).

\section{CONCLUSION}

This research has discussed the importance of assessing intercultural competence (IC) of one's own in general and the state junior high school English teachers in Yogyakarta Special Region province in particular. Regarding the research findings, the state junior high school English teachers in Yogyakarta Special Region province possess a high level of intercultural competence (IC). This indicates that they have high respect for cultural differences; they are able to behave pertinent to the proposed indicators (attitude, skill, and knowledge) properly. This result also reflects that they seem to perceive well on what they have understood about cultural differences, values, and norms so that they are able to easily input several cultural elements into their teaching and learning process.

Besides, the state junior high school English teachers in Yogyakarta Special Region province have a high level of intercultural attitude (IA). This shows that they are considered to be able to succeed in intercultural interaction since they are open-minded with other people's cultures, beliefs, and behaviors. They are also supposed to have the attitudes of curiosity and openness, and of readiness to suspend judgment based on first impressions when they meet other people in an intercultural encounter. Moreover, they can interact positively without the certainty of what the other thinks and feels. This also means that they have applied their intercultural attitude through their action of a conversation with other people.

Furthermore, the state junior high school English teachers in DIY own a high level of intercultural skill (IS). It means that they have the ability to interact with other people who have different knowledge and skill of problem-solving as well as collaborating with others. It also expounds that the state junior high school English teachers have shown their critical thinking. For example, they use all available information and their analytical skills to verify their interpretations.

Moreover, the state junior high school English teachers in DIY possess a high level of intercultural knowledge (IK). This high intercultural knowledge expounds that the state junior high school English teachers have shown their understanding of different 
kinds of interaction that it has different aims and rules. In other words, they realize that every communication with other people who have different goals and rules needs knowledge about social practices so that misunderstanding can be minimized. In addition to this, the state junior high school English teachers also seem to be active in exploring the reasons behind different practices and reactions when they conduct a conversation with other people who show different behaviors or attitudes.

Another research finding shows that all the state junior high school English teachers have the same level of IC, and the locations where they teach do not influence their level of intercultural competence (IC). In other words, the four districts (Bantul, Kulon Progo, Gunung Kidul, Sleman) and the city of Yogyakarta in Yogyakarta Special Region province have no significant influence pertaining to the level of intercultural competence (IC) of the state junior high school English teachers in DIY.

\section{Acknowledgments}

The author would like to extend immense gratitude to the LPDP scholarship for the funding of this small research without which this research may not be possible.

\section{REFERENCES}

Altan, M. Z. (2018). Intercultural sensitivity: A study of pre-service English language teachers. Journal of Intercultural Communication, 46(1), 1-17.

Bennet, M. J. (1993). Towards ethnorelativism: A developmental model of intercultural sensitivity. In R. M. Paige (Ed.), Education for the intercultural experience ( $2^{\text {nd }}$ ed., pp. 21-71). Yarmouth, ME: Intercultural Press.

Borghetti, C. (2017). Is there really a need for assessing intercultural competence? Some ethical is sue. Journal of Intercultural Communication, 44(1).

Byram, M., Gribkova, B., \& Starkey, H., (2002). Developing the intercultural dimension in language teaching: A practical introduction for teachers. Strasbourg: Council of Europe Publishing.

Byram, M. (1997). Teaching and assessing intercultural communicative competence. Clevedon: Multilingual Matters.

Cubukcu, F. (2013). Pre-service English teachers' intercultural sensitivity. International Journal of Human Sciences, 10(1), 832-843.

Deardorff, D. K. (2006). Identification and assessment of intercultural competence as a student outcome of internalization. Journal of Studies in International Education, 10(3), 241-266. doi: $10.1177 / 1028315306287002$.

Delors, J. (1996). Learning, the treasure within: Report to UNESCO of the international commission on education for the twenty-first century. Paris: UNESCO Pub.

Fantini, A. E. (2006). Assessment tools of intercultural communicative competence. Brattleboro: Vermont.

Fantini, A. E. (2009). Developing intercultural competence: An educational imperative for the $21^{\text {st }}$ century. Studies in Language and Literature, 28(2), 192-213.

Fungchomehoei, S., \& Kardkarnkali, U. (2016). Exploring the intercultural competence of Thai secondary education teachers and its implications in English language teaching. Procedia-Social and Behavioral Science, 236(1), 240-247. doi: 10.1016/j.sbs pro.2016.12.017

Guncavdi, G., \& Polat, S. (2016). Level of intercultural competence of international students at kocaeli university. Universal Journal of Education Research, 4(12), 39-45. doi: 10.13189/ujer.2016.041306.

Hong, S. (2008). The role of heritage students in incorporating culture into language teaching. South Asia Language Pedagogy and Technology, 1(1).

Huber, J., \& Reynolds, C. (2014). Developing intercultural competence through education. Paris: Council of Europe Publishing.

Idris, M. M. (2019). Intercultural communicative competence (ICC): What should Indonesian EFL teachers have related to ICC's elements? Journal of English Language Teaching and Linguistics, 4(1), 67-76.

Kementerian Pendidikan Dan Kebudayaan.(2013). Kurikulum 2013: Kompetensi dasar sekolah menengah pertama (SMP)/madrasah tsanawiyah $(M t s)$. Retrieved from https://www.academia.edu/7117429/KURIKULU M_2013_KOMPETENSI_DASAR_Sekolah_Men engah_Pertama_SMP_Madrasah_Tsanawiyah_M Ts.

Kramsch, C. (2013). Culture in foreign language teaching. Iranian Journal of Language Teaching Research, 1(1), 57-78.

Lazar, L. (2008). Recognising intercultural competence: What shows that I am interculturally competent? Pestalozzi programme and the intercultural cities project of the council of Europe/European commission and the European wergeland centre. Retrieved from https://www.coe.int/t/dg4/education/pestalozzi/So urce/Documentation/ICCTool2014/ICToolGB.pdf

Madya, S. (2013). Metodologi pembelajaran bahasa: Dari era pra-metode sampai era pasca-metode. Yogyakarta: UNY Press.

Pajak-Wazna, E. (2013). Teachers' intercultural competence and teacher education: A case of Poland. European Scientific Journal, 1(1), 318322. doi: 10.19044/esj.2013.v9n19p\%p

Rajic, V., \& Rajic, T. (2015). Assessment of intercultural competence of vocational teachers in 
Croatia. Andragoskaspoznanja, 21(4), 37-51. doi: 10.4312/as.21.4.37-51.

Scarino, A. (2009). Assessing intercultural capability in learning languages: Some issues and considerations. Language Teaching, 42(1), 67-80. doi: 10.1017/SD2614444808005417.

Setiadi, R. (2018). Assessing Indonesian's students' competence in translating French texts of different types. Indonesian Journal of Applied Linguistics, 8(1), 91-99. doi: 10.17509/ijal.v8i1.11477

Shuguang, S., \& Qiufang, W. (2018). Teacher-student collaborative assessment (TSCA) in integrated language clas rooms. Indonesian Journal of Applied Linguistics, 8(2), 369-379. doi: 10.17509/ijal.v8i2.13301

Sudhoff, J. (2010). CLIL and Intercultural communicative competence: Foundations and approaches towards a fusion. International CLIL Research Journal, 1(3), 30-37.
UNESCO, (2006). Guidelines on international education. Paris: UNESCO Headquarters.

Widoyoko, E. P., (2009). Evaluasi program pembelajaran: Panduan praktis bagi pendidik dan calon pendidik. Yogyakarta: Pustaka Belajar.

Wu, C. H. (2015). Assessing intercultural communicative competence through EFL students' writing: A case study in a college language class. Paper presented at The 2015 LTTC international conference, National Taiwan University, Taiwan.

Xiaole, M., Meng, M., \& Manli, L. (2012). A survey on teachers' perception and practice of ICC assessment of university English learners in China. Intercultural Communication Studies, 21(1), 205220.

Zheng, J. (2014). Asses sing intercultural communicative competence in college English teaching. International Journal of English Language Teaching, 1(2), 73-77. doi: 10.5430/ijelt.v $\ln 2 \mathrm{p} 73$ 